\title{
Types and biotic successions of Ordovician reefs in China
}

\author{
WANG JianPo ${ }^{1}$, DENG XiaoJie ${ }^{2}$, WANG Guan ${ }^{2} \&$ LI Yue ${ }^{2 *}$ \\ ${ }^{1}$ Wuhan Center of Geological Survey, Wuhan 430205, China; \\ ${ }^{2}$ Nanjing Institute of Geology and Palaeontology, Chinese Academy of Sciences, Nanjing 210008, China
}

Received October 21, 2011; accepted December 8, 2011; published online January 31, 2012

\begin{abstract}
Ordovician reefs are located in the South China, Tarim, and North China blocks, in low-latitude epicontinental marine regions and mostly consist of large-scale carbonate platforms. During the Paleozoic, faunal radiation reef biota diverged and thrived in diverse paleogeographic settings. Algal reefs of the Early Ordovician, Calathium-lithistid sponge-algal reefs of the late Early Ordovician to early Middle Ordovician, and coral-stromatoporoid-algal reefs of the early Late Ordovician, indicate change from Cambrian to Paleozoic biota. Coral-stromatoporoid-algal reefs were the basic communities after $100 \mathrm{Ma}$. The macroevolution of biotic structures generally shows increased complexity; the evolution of China's reef biota parallels that worldwide. Important aspects are: (1) The Calathium-algal reefs from the early Tremadocian Nantzinkuan Formation, Zhangjiajie, western Hunan are the pioneer reefs, and the Darriwillian Yijianfang Formation, Bachu are the relic reefs. (2) The bryozoan-dominated reefs of the late Tremadocian Fenhsiang Formation, Middle Yangtze Platform are unique. (3) The early coral-stromatoporoid-algal reefs are highly restricted in China. (4) The algal reefs from the latest Katian on the western margin of the Yangtze Platform, represent an abnormal reefbuilding environment during the initial stages of Gondwanan glaciations.
\end{abstract}

China, Ordovician, reef biota, evolution, paleogeography

Citation: Wang J P, Deng X J, Wang G, et al. Types and biotic successions of Ordovician reefs in China. Chin Sci Bull, 2012, 57: 1160-1168, doi: $10.1007 / \mathrm{s} 11434-011-4936-7$

Reefs are considered cradles of biodiversity, their ecological innovations triggered by distinctive replacements of reefbuilding biota over geological time [1]. Proterozoic stromatolites had improved the living conditions of the hydrosphere and atmosphere for a long time before the emergence of metazoa. Conspicuous reefs constructed by Namacalathus, together with calcified microbes of the end-Proterozoic Nama Group in Namibia, Africa [2], indicate the important role of metazoans in the reef ecosystem. Phanerozoic reef styles show coexistence of algal (including cyanobacterial and calcareous algal) [3] and metazoan-algal components, with the latter being more common [4]. Abundance of microbial carbonate has usually been inversely proportional to metazoan diversity [5]. The Great Ordovician Biodiversification Event [6-8] promoted pluralistic reef ecosystems constructed by Paleozoic fauna and algae,

*Corresponding author (email: yueli@nigpas.ac.cn) and spanned $45 \mathrm{Ma}$.

The macroevolutionary patterns of most metazoan taxa have been outlined based on the biodiversity from facies at different depths in the South China Block [9-12]. However, reefs have great potential for highlighting the changeover processes of differing ecosystem rank during the Great Ordovician Radiation. The monotonous bryozoan-lithistid sponge-Calathium reef communities of the Early Ordovician witnessed new episodes of metazoan reef development. The initiation of coral-stromatoporoid-algal reef communities of the Middle to Late Ordovician marked complete innovations in the frame builders, which then remained steady from the Silurian to the Devonian. The Gondwana margin, Laurentia, and Siberia have preserved the majority of the approximately 200 recorded Ordovician reefs [13,14]. About 40 are well represented in the South China, Tarim, and North China blocks [15]. An updated global Ordovician division scheme and a database concerning this theme pro- 
vide the possibility of reconstructing the scenario of reef succession in China. We are doubtful of some "reefs" described in some publications from the field investigations of recent years. Reef dating follows the current geological time scale. Descriptions of paleoecological characteristics are in accordance with reef biota.

\section{Temporal and spatial distribution and reef components}

\subsection{South China Block}

The Ordovician reefs of South China have been reviewed $[16,17]$, however some reefs have not been mentioned. Figure 1 shows reef occurrence for each epoch in the paleogeographic setting of South China.

Stromatolites that are laminar, domical, columned, and ramose-columned occurred in the early Tremadocian Nantsinkuan Formation in Songzi County, Hubei [18]. Their morphological diversity, from laminar to columned, was influenced by sea level rise [18]. Reefs formed by Calathium and overlapping algae at Wentang, Zhangjiajie, in western Hunan, are found in the margins of the Yangtze Platform. The $0.8-1.2 \mathrm{~m}$ thick reef base is shoal facies dominated by pelmatozoans and a few brachiopods, cephalopods, bivalves, and trilobite fragments, with parallel bedding and medium-scale cross-bedding. The lower reef core is comprises $1.2 \mathrm{~m}$ of Calathium bafflestones and microbial bindstones. The 1.8-2.0 $\mathrm{m}$ of microbial coverstones and bindstones with less Calathium are found in the middle and upper parts of the reef core [19]. The earliest tabulate coral, Catenipora, occurs sparsely [20].

Late Tremadocian reefs illustrate distinctive differentia- tions of communities and lithofacies from the near shore to the platform margins. In 2009, we discovered 1-m-thick dolomitization column-shaped stromatolites from the top of the Tongtzu Formation at Wudang, Guiyang, in a near shore setting that was typically evaporated and anomalous salinity. The coeval reefs of the Fenhsiang Formation in Yichang had more complex communities; they are overlapped, scattered domical, or stratoid in morphology, and a variety of types including lithistid sponge-microbial reef, bryozoan reef, lithistid sponge-bryozoan reef, and Calathium-lithistid sponge-microbial reef $[16,17]$. The bryozoan patch reefs at Chengjiahe, Yichang, are 23-30 cm wide and 5-10 cm thick. Rocks of the reef core are $32.05 \%$ Nekhorosheviella (bryozoans) and $37.90 \%$ pelmatozoans [21]. Ten-meter thick columned stromatolites extend from the middle part of the Lunshan Formation, Shitai, southern Anhui, toward the southeast margin of the Yangtze Platform. Individual columns are $20-50 \mathrm{~cm}$ thick and less than $20 \mathrm{~cm}$ in diameter. The distances between the columns are from several centimeters to a few meters [16].

The early Floian Hunghuayuan Formation reefs can be viewed as the index beds for stratigraphic correlation on the Yangtze Platform, because their distribution can be tracked from northern Guizhou to southern Anhui covering the region from the western part to the southeastern margin [22]. Reefs from this area are the most frequently reported in the literature. A Calathium-Archeoscyphia-microbial community forms reef bafflestones in Zhangzhai, Yuping, Guizhou. Individual reefs are more than $2.5 \mathrm{~m}$ or even up to $10 \mathrm{~m}$ in thickness with talus collapsed from the reef core [23]. In the central Yangtze Platform, Yichang, western Hubei, a diverse range of reefs occur. They are scattered, overlapped domical, lenticular, stratoid, irregular patch reefs, and are

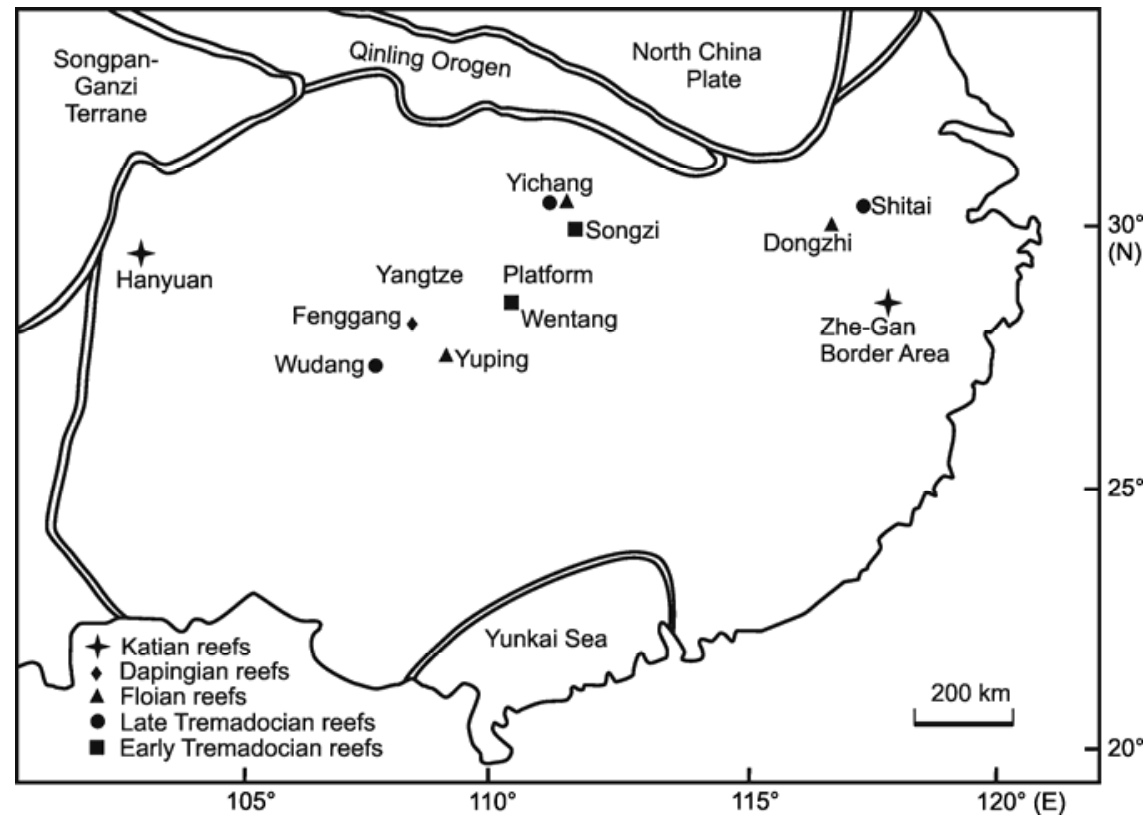

Figure 1 Temporal and spatial distributions of Ordovician reefs in South China. 
dozens of centimeters to several meters in thickness. Reefs have abundant Calathium, Archeoscyphia, and algae. Pulchrilamina (stromatoporoid) fossils are locally abundant. Community replacement is exhibited, from Calathium-Archeoscyphia to Calathium-microbes [17,24]. Toward the southeastern margin of the platform, reefs are dominated by the calcified microbe Girvanella. Calathium (lithistid sponges) are common reef dwellers; forming Calathium/lithistid spongemicrobial reefs in Dongzhi, southern Anhui [25].

The early Dapingian reef is restricted to the Yangtze region. Two layers of Calathium biostromes occur in the Middle Limestone, Meitan Formation at Dongkala, Fenggang, northern Guizhou. The thicknesses of the lower and upper layers are $15 \mathrm{~cm}$ and $30-40 \mathrm{~cm}$ respectively. Calathium fossils are generally small in size, around $1.5-4 \mathrm{~cm}$ in diameter, forming $20 \%$ of the rock volume and are taphonomically allochthonous. Lithistid sponges are low in abundance; however, the area is rich in crinoid, bryozoan, gastropod, brachiopod, and trilobite fragments. Other algal bioclastic components include Girvanella, dasycladaeae, and codiaceae. Communities in these biostromes show typical warm marine facies [26].

Marine facies covered the northeastern marine region of the Cathaysian Land in Yushan, Changshan, and Jiangshan (Sanshan area), Zhejiang (Zhe), and the Jiangxi (Gan) border area during the later Kaitian, Late Ordovician. Reef complexes occur on the platform sequence of the Xiazhen Formation and the platform margin sequence of the Sanqushan Formation. The Changwu Formation shales indicate an outer-shelf belt [16]. Algal reefs extend along the platform margin and top of the slope. Mounds show low relief, are arranged in groups, and of diverse size from several meters to tens of meters high, and usually several meters to more than 50 meters long. Minor mounds have lengths less than 1 $\mathrm{m}$. The reef-building belt is about $100 \mathrm{~m}$ thick and $1 \mathrm{~km}$ wide. The patch reef group of the Xiazhen Formation is gentle in morphology and composed of coral-stromatoporoid-algae. Patch reefs are scattered on the shallow marine regions of the platform, from $10 \mathrm{~m}$ to more than $100 \mathrm{~m}$ in thickness, and from several hundred meters to thousands of meters in length; these are coalesced mounds. Stromatoporoidal biostromes also extend across the platform [16]. A coral-stromatoporiod reef community is intercalated with carbonate mud mounds at Wangjiaba, Yushan, at the platform margin. The Sibiriolites jiangxiensis (coral) community characterized by branching and irregular, massive coral, is considered the reef base, in which corals, brachiopods, and bryozoans are found. Small rugose corals such as the conical Streptelasma are abundant. Rhynchonellids had a major role in the brachiopod fauna. The Fletcheriella grandis-Pachystylostroma community of the reef core is composed of corals, stromatoporoids, bryozoans, and algae. Coral elements include Fletcheriella, massive agetolitedaeplasmoporellidae, and heliolitedae. Stromatoporoidal elements forming frameworks include Pachystylostroma and
Ecclimacodictyon. Algal elements include Solenopora and Vermiporella. A trilobite community of Trocholites-Encrinoroides surrounds the reef [27-30].

The Upper Katian Daduhe Formation on the western margin of the Yangtze Platform is comprises terrigenous clastic rocks intercalated with limestone [31]. Algal patch reefs and atolls mainly occur in the Jiaodingshan and Dawashan sections in Hanyuan. The patch reefs are from $20 \mathrm{~m}$ to several hundred meters (or only $2 \mathrm{~m}$ ) in diameter. The $14 \mathrm{~m}$ thick patch reef at Dawashan has obviously distinguishable subfacies of reef core and reef flank. Arrangements of patch reefs illustrate subfacies at front, flat, and back. The maximum diameter of the atoll at Jiaodingshan is about $1 \mathrm{~km}$ and composed of the reef core, talus on the reef flank, and a lagoon. Reef rocks are rich in rhodochrosite, manganesebearing dolostone, and limestone. Oolites are common at Jiaodingshan, and, in contrast, algal filaments, stromatolites, and oncolites are common at Dawashan [31]. Algal elements of Epiphyton, Frutexites, Rivularia, Dasycladus-solenoporaceae, and Actinophycus formed phylloid-shaped bafflestones and bindstones [32]. Webby [15] considered that these were more likely mat-like growths formed by Trichonophyton.

\subsection{Tarim Block}

The Lower Ordovician sequences from North Tarim Oil Field, Tahe Oil Field, and the Central Uplift are dominated by dolostones. Limestone facies began in the Middle Ordovician. The Darriwilian Yijianfang Formation and the early Katian Lianglitag Formation are notable for reef occurrence (Figure 2), and were key targets for carbonate-type reservoirs.

Bachu outcrop, northwest of the Central Uplift, is comprised of grayish Calathium reefs from the lower part of the early Darriwilian Yijianfang Formation. The reef dwelling biota has been recorded in detail $[33,34]$. These patch reefs have sharp margins. More than 20 are larger than $10 \mathrm{~m} \times 5 \mathrm{~m}$ in size. Reef bases are pelmatozoanal limestones with occasional erosion surfaces and cross-bedding. Micrite envelopes partially cover the surfaces of pelmatozoanal grains. Calathium bafflestones and algal contents make up the main framework, which can be locally $60 \%-80 \%$ of the rock volume. Sand-size algal fragments are abundant. Subfacies of reef cores are formed by microbial lamina and lithistid sponges. In the lower reef core, pelmatozoanal fragments fill the spaces in the Calathium bafflestone. Algal mudstones are abundant in the upper reef core and coexist with bioclastic wackestone. Pelmatozoanal limestones and sandsized intraclastic pelmatozoanal limestones are deposited both on the reef top and reef flank facies [35-37]. Coeval reefs are also found in the Dawangou Formation at Aksu, Kalpin Block [17], and the Yijianfang Formation of North Tarim [17]. Algal reef and Calathium-algal reef occur in the Luoxi Carbonate Platform [38] and Well Gucheng 4 [39]. 


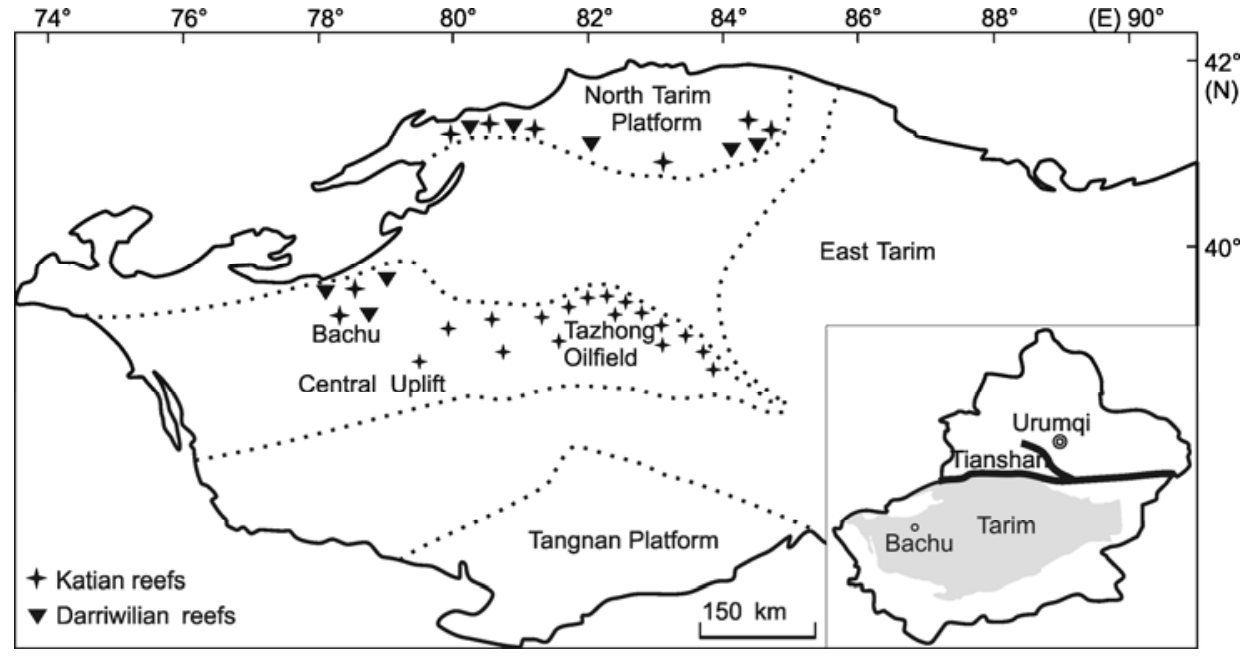

Figure 2 Temporal and spatial distributions of Ordovician reefs in the Tarim Block.

The Lianglitag Formation reefs have a wide distribution and diverse community structure. Three phases of algal mounds outcrop at Bachu. Reefs of Phase 1 and Phase 3 are light gray carbonate mud mounds formed by calcified microbes that bind peloids, lime mud, oncoids, and ooids. Algal patch reefs of Phase 2 are notable red limestones. Patch reefs are concentrated in the northern Lianglitag Mountains, covering about $10 \mathrm{~km}^{2}$. Major patch reefs are about $30 \mathrm{~m}$ thick vertically stacked into three sub-mounds, surrounded by thinner satellite reefs. The growth style of satellite reefs can show vertical sequences expanding from small patches (about $1 \mathrm{~m}$ thick, several meters in diameter, or smaller) to $20 \mathrm{~m}$ in diameter and meters in thickness. Reef flanks are nodular limestones. The biotic elements of these patch reefs include Girvanella, Renalcids, Ortonella, and Vermiporella $[40,41]$. Diverse communities differing in biotic components and lithological framestones, bafflestones, and bindstones occur from the drilling wells of the Lianglitag Formation in the Central Uplift and the Lunnan Oil Fields. Some reef units exhibit stromatolitic textures. Bioclastic, oncolitic, intraclastic shoals are also abundant. Reef complexes of the Lianglitag Formation along the slope-break have high biodiversity. Algal taxa include Girvanella, Renalcis, Nuia, Dasycladus, Dasyporella, Eogonilina, Vermiporella, Hedstroemia, Solenopora, Sphareacodium, Coelospheridium, and Prototoxites. Lithistid sponges include stromatoporoids such as Labechia, Densaatroma, Shandongpora, and Dictyopora. Corals include Yohophyllum, Tetradium, Heliolites, Syringopora, Chaetites, Amsassia, Catenipora, and pachyporidae. Bryozoa include Nicholsonella, Hallopora, Stictoporella, Batostoma, Diplotrypa, Atacotoporella, and Trepocryotopora. Reef dwelling biota include ostracods, trilobites, gastropods, brachiopods and echinoderms [42].

Coeval to the Lianglitag Formation, the carbonate platform sequence of the Ulikzitag Formation in Kuruketag, eastern Tarim, contains allochthonous coral gravels. We suggest that coral reef-building subtly existed at the south margin of the carbonate platform near the Xingdi Fault.

\subsection{North China Block}

The incompleteness of the Ordovician strata especially the frequent occurrence of dolostones in the eastern North China Block results in an absence of reefs. In northern Weihe, reefs are exhibited in the platform facies of the Sandbian Yaoxian Formation and the platform margin facies of the middle Katian Beiguoshan Formation, in the western part of the North China Block (Figure 3).

Several layers of lentoid and stratoid reefs constructed by corals, stromatoporoids, and algae occur throughout the middle-upper part of the Yaoxian Formation, Longxian, and Fuping, on the southern margin of Ordos Land. The reef layers yield algal taxa including Girvanella, Renalcis, Epiphyton, Phacelophyton, Solenopora, Vermiporella, and Trichophyton; corals including Lichenaria, Cryptolichenaria, Eoflecheria, and Amssia; and stromatoporoids including Forolinia. Stromatolites, calcified microbial-algal bafflestones,

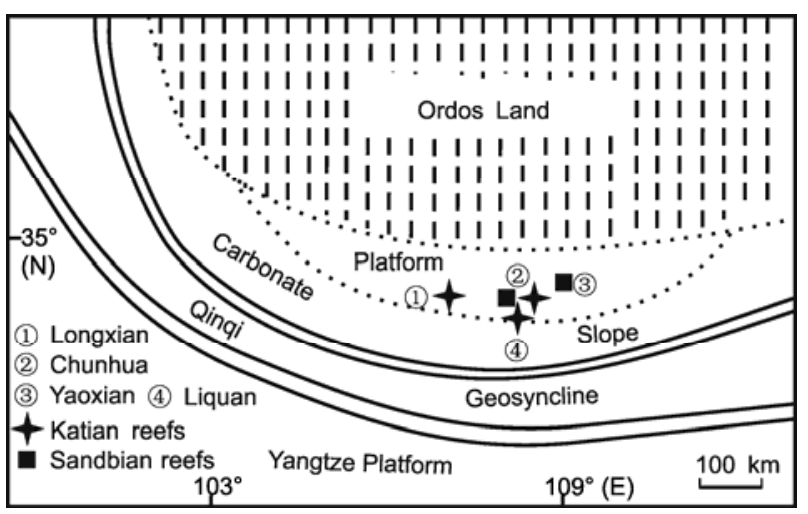

Figure 3 Temporal and spatial distributions of Ordovician reefs in Ordos, on the western margin of the North China Block. 
coral-stromatoporoid framestones, and coral-calcified algal bafflestones are essential components of these reef frameworks. The reef sequences are $610 \mathrm{~m}$ thick in total, at Tiewadian, Chunhua, and talus and stromatoporoids enveloping gravels are very common $[43,44]$.

Coral-stromatoporoid-algal reefs occur in the Beiguoshan Formation in Longxian and Liquan. The reef complex in Longxian is $80 \mathrm{~m}$ thick and composed of six mounds vertically. The main contributors are Girvanella, Hedstroemia, Ajakmalajsoria, Solenopora, and Palaeoporella (algae); Favistina, Paleofavosites, Syringoporella, and Halysites (corals); Ecclimadictyon and Clathrodictyon (stromatoporoids). Reef dwelling taxa include bryozoans, pelmatozoans, brachiopods, trilobites, and gastropods. Types of framework are algal bafflestones, microbial bindstones, coral framestones, and stromoporoid framestones. Deeper marine silty shales overlap the reef top [45]. Reef types vary depending on the paleogeographic setting. This is illustrated by the richer coral-stromatoporoid frameworks and the higher biodiversity of reef dwellers in the inner platform. In contrast, mounds dominated by algal bindstones are likely to occur near the platform margin, as are found at Longmendong, Longxian.

\section{Succession of the reef-building taxa}

Successive emergence of metazoans and algae was an essential part of the Ordovician Radiation. The examples cited above show that the main Ordovician reef-building organisms in China were algae, sponges, bryozoans, corals, and stromatoporiods. These are proxies for special periods and environments favorable for reef development. Figure 4 catalogues the communities formed by key reef-building organisms and the paleogeography of stratigraphic units.

Prokaryotes (without membrane-bound nuclei, also called calcified microbes [46]) are mainly preserved as stromatolites, thrombolites, oncoids, and peloids. They can also encrust other reef builders resulting in rigid frameworks, and persisting in major roles over geological time.

Ordovician reef microbes in China prominently include Girvanella, Renalcids, Ortonella, Hedstroemia, Garwoodia, and Rothpletzella [17,25,29,42]. These were generally thriving in the Early Ordovician, but declined somewhat from the Middle Ordovician. Reefs dominated by stromatolites and thrombolites are represented by the Nantsinkuan Formation, Songzi, Hubei [18], the Lunshan Formation, Shitai [16], and the Hunghuayuan Formation, Dongzhi, southern Anhui [25,47]. Green algae and red algae with calcified cytoderms could baffle and bind particles, and their lithological proportions rose steadily from the Darriwilian period [15]. Calcareous algae, however, reinforced reef-building in China until the Late Ordovician [28,30,42,45]. Vermiporella (green algae) and Solenoporella and Sphaerocodium (red algae) show local abundance in the reef.
Sponges radiated initially during the Ordovician Period. Lithistid sponges, especially Archaeoscyphia (orthocladina), are predominant in reefs in the Early Ordovician [15], but declined in the Middle to Late Ordovician [48]. Spongeassociated reefs in China were mainly reported from the Early Ordovician strata of the Yangtze Platform [17,23] and the Lunnan Oil Field, Tarim [35]. Conical Calathium is a common sponge in these deposits [49]. Early to Middle Ordovician reef communities, represented by algal-Calathium and/or lithistid sponge associations, had similar characteristics as the Yangtze Platform and Tarim Block [17,37].

On the Yangtze Platform, the Early Ordovician Nekhorosheviella and Orbiramus (bryozoan) aggregations formed reefs and shoals $[21,50]$. Bryozoans can be unique reef contributors [16]. Bryozoans became part of the typical reef framework from the Darriwilian stage [15]. Diversity of bryozoans increased during the Late Ordovician. These enrich reefs in Tarim and the Zhejiang-Jiangxi border area $[28,29,40,42]$.

Monotonous reef communities composed of algae, Calathium, and lithistid sponges represent the initial period of the Ordovician Radiation Event. However, rugose corals and tabulate corals with their morphological complexity and specialization potential, led to dramatically high biodiversity in reefs by the climax of the radiation [37]. The earliest tabulate coral Lichenaria, had a weak role during the EarlyMiddle Tremadocian [51]. Coral-associated reefs started in the late Darriwilian. Solitary rugose corals are scattered in some horizons of the Yangtze Platform. But coral frameworks partly building the reef were delayed until the early Late Ordovician Yaoxian Formation at Ordos [43,44]. Corals are commonly found in the Upper Ordovician strata at Ordos, Tarim, and the Zhejiang-Jiangxi border area. Tabulate corals are considered the dominant constructers of frameworks $[28,29,42,45]$. Rugose corals are subordinate in reef limestones $[42,45]$.

Stromatoporoids, such as Pulchrilamina, arose locally as reef partners during the Early Ordovician [15,52], and are sporadically recorded from the Lower Ordovician Hunghuayuan Formation on the Yangtze Platform. The stromatoporoid Forolinia constructed reef frameworks in the Sandbian Yaoxian Formation at the west margin of the North China Block [43,44]. Typical metazoanal communities formed by stromatoporoids and corals of the Late Ordovician are very common, and these reach large dimensions in the Zhejiang-Jiangxi border area, Tarim, and Ordos $[27,42,45]$.

\section{Types and community successions}

Webby [15] cited reef examples from China when he dated eight reef-forming phases through Ordovician time. We verified reef ages and used updated materials. We provide a perspective on an evolutionary phase of a specific community 


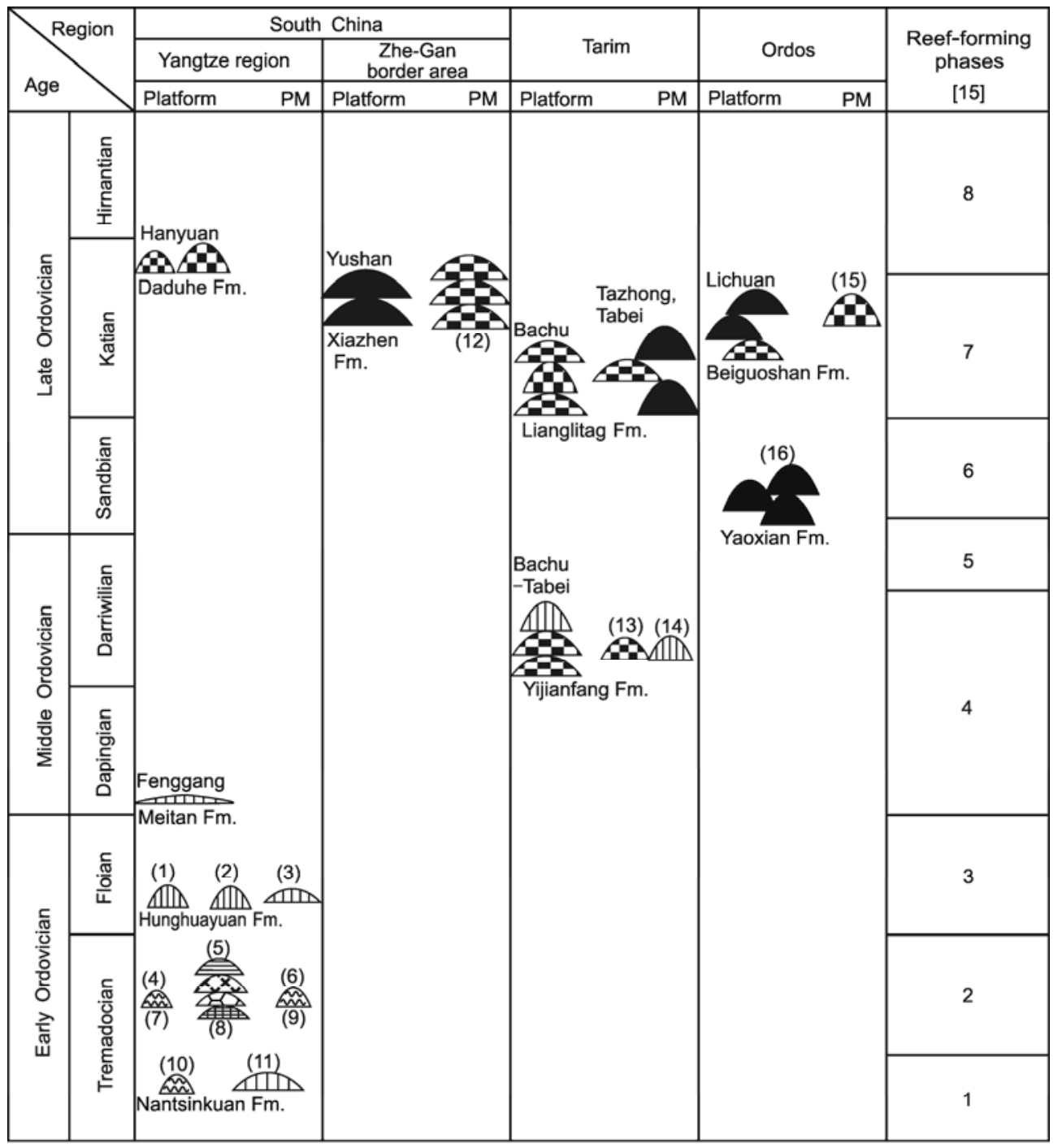

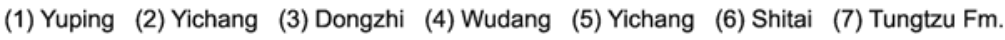

(8) Fenghsiang Fm. (9) Lunshan Fm. (10) Songzi (11) Zhangjiajie (12) Yushan-Changshan Sanqushan Fm.

(13) Luoxi (14) Gucheng (15) Longxian (16) Longxian-Fuping-Chunhua PM: Platform Margin

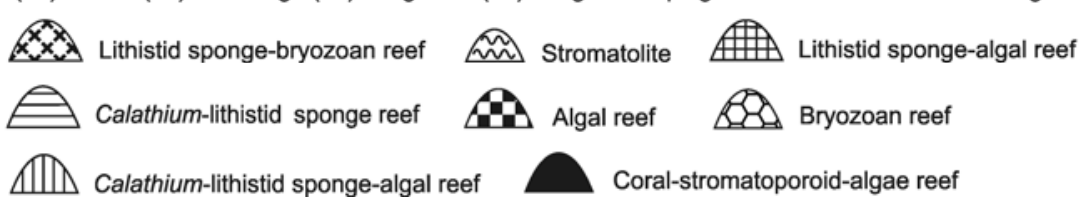

Figure 4 Reef types and reef-building phases during the Ordovician in China.

during the Great Ordovician Radiation Event (Figure 4).

Phase 1 (early Tremadocian): Reef structures followed the Cambrian absolute predominance of stromatolites and thrombolites. Metazoan reefs associated with Lichenaria (tabulate coral) and lithistid sponges only occurred in Newfoundland, Canada (Laurentia) [53,54]. Small stromatolites on the Yangtze Platform represented the mainstream reef communities at this time. The occurrence of Calathium reef from the platform margin, western Hunan, was earlier than in the example cited by Webby [15], although it is spatially limited and weak in content. It seems likely that it marks the initiation of algal-Calathium-lithistid sponge reef communities. The earliest tabulate coral, Catenipora [20], within this reef, is significant for the dating of diverse patterns of tabulate coral during the earliest Ordovician, and verifies the hypothesis that reefs are cradles of evolution and sources of biodiversity.

Phase 2 (late Tremadocian): A wider range of stromatolitic and thrombolitic reefs existed and reached their acme. Calathium and/or lithistid sponges also dominated by volume. This reef type had a wide spatial distribution during the Early-Middle Ordovician. The bryozoan reef in the 
Fenhsiang Formation, Yangtze Platform, is a good example [16]. The facies differentiation of this phase is illustrated by the arrangement of near-shore dolomitization stromatolites of the Tongtzu Formation, the off-shore bryozoan reef of the Fenhsiang Formation, and the platform margin stromatolites of the Lunshan Formation. This implies that stromatolites were likely attracted to the near-shore anomalous salinity, and to the deeper marine environments of the platform margins, while metazoan frameworks grew in the central platform.

Phase 3 (Floian): Phase 3 does not include any essential alteration from Phase 2, in terms of the reef-building biota. Nevertheless, Pulchrilamina (a pioneer stromatoporoid), is an important reef-building taxon. Reef communities of this period are exemplified in the Hunghuayuan Formation, Yangtze Platform [22].

Phase 4 (Dapingian-Early Darriwilian): The Dapingian is still dominated in volume by Calathium-lithistid spongealgal communities elsewhere in the world. Mud mounds in Russia as well as large stromatactis-bearing mud mounds in Nevada emphasize the coexistence of biotic structures. Calathium-lithistid-sponge-microbial reef communities declined abruptly from the Darriwilian, on a global scale. A limited occurrence in the Yijianfang Formation, Tarim, is thus interpreted as a relic Calathium reef [37].

Phase 5 (Late Darriwilian): The dramatic reef community replacement of the Ordovician happened during this time. The emergence of corals, stromatoporoids, bryozoans, and algae, together with subsisting lithistid sponges and calcified microbes, were contributors to greater community complexity than previously. This reef type persisted over the next 100 million years. The three Chinese blocks do not have reefs of this phase.

The Phase 6 (Sandbian, former Early Caradocian): Reef communities have a heritage from Phase 5. Metazoan biodiversity reached an acme. Reefs have mostly been documented from the shelves surrounding Laurentian Land. They are diverse in type, and include reef builders such as tiny tube-like worms, stromatoporoids, and Tetradium (coral), from the intertidal zone, and the equivalent small to larger corals, stromatoporoids, and bryozoans from the subtidal zone. Small sponge-algal reefs occurred locally. Large bryozoan-dominated reefs appeared at shelf margins and down the slope. The Yaoxian Formation reef from the western North China Block is consistent with this in time and biotic structure, and is thus viewed as the earliest coralstromatoporoid reef in China, even though it is limited to southern Ordos.

Phase 7 (Katian, former middle-late Caradocian): Reef habitations were widespread and are represented by the microbial-algal mud mounds in the tectonic belts fringing the islands of Kazakhstan, and the stromatoporoid, coral, and Solenopora reefs in Norway. Coral-stromatoporoid-algal reefs, with various community structures, occur on all the three blocks in China [27,32,42]. The reef-shoal complexes of the early Katian Lianglitag Formation have the broadest distribution and cover the whole platform. Reefs of the middle Katian in Ordos, late Katian in the northwest marine of Cathaysia Land, and the end-Katian on the west margin of Yangtze Platform, show as facies differentiation horizontally The end-Katian Daduhe Formation microbial-algal mud mounds from the west margins of the Yangtze Platform are probably evidence of anomalous salinity [55] caused by the beginning of the latest Ordovician glaciation [32].

Phase 8 (Hirnantian): The latest Ordovician glaciation resulted in mass extinction and abruptly affected reefs. During the interval between the early Hirnantian and the beginning of the Silurian, mud mounds yielding bryozoans and pelmatozoans grew in the high paleolatitude belt along the Gondwanan margin [15]. Although local warm water environments existed in the shoal belts of the Yangtze Platform, Chinese reefs of this period have not been reported.

To summarize Ordovician reef formation in China: Early Tremadocian reefs mainly succeeded the Middle-Late Cambrian calcified microbial communities, and gestated pioneer coral fauna. Algae, Calathium, lithistid sponges, bryozoans, and the stromatoporoid, Pulchrilamina, formed reefs from the late Tremadocian to early Darriwilian. The metazoan taxa that originated from the late Tremadocian are frequently or only discovered in reef facies; thus providing evidence that reefs are cradles for special biomes [1]. The early Darriwilian reef-building communities implied intense hereditability from the Floian, and were rarely composed of bryozoans and stromatoporoids. Global biodiversity of hermatypic bryozoans, corals, and stromatoporoids increased abruptly during the late Darriwilian. Late Ordovician corals, stromatoporoids, and algae are dominant in reef rocks. Meanwhile, calcified microbes and algae were able to form reefs in special environments. Reef communities therefore entered into a pluralistic epoch.

\section{Conclusion}

Oceanographic factors such as water temperature, oxygen content, nutrients, and sea level changes constrain reefs spatially as well as differentiate their facies, and even play various roles geographically. It is convincing that the spatial and temporal distributions and the community structures of reefs are proxies for their environments. Sea level fluctuations controlled reef growing spaces and morphology. Reef organisms were variously sensitive and formed strategies to cope with alterations in physical and chemical conditions in marine water. Algae as primary producers in marine ecosystems might have during the Ordovician avoided predator pressures from the Paleozoic Faunal Radiation. The calcification of cyanobacterial sheaths appears to coincide with global greenhouse episodes [56]. The greenhouse-like temperature of the Late Cambrian to Early Ordovician exceeded 
the tolerance of most stenothermal reef organisms [57], and resulted in the slow radiation of corals and stromatoporoids after their origination. The high concentrations of atmospheric carbon dioxide in the early Early-Middle Ordovician caused the oceans to acidify [15], thus preventing coral and stromatoporoid radiation. During greenhouse episodes, algal and coral-sponge reefs consistently grew in lower latitudes, while coral reefs occurred at higher latitudes, and bryozoans dominated reefs formed in the highest latitudes (about $23^{\circ}$ in the Paleozoic). It is generally suggested that coral and stromatoporoid reefs probably grew in oligotrophic conditions, and that microbes occupied the mesotrophic regions. But the Early Paleozoic reef builders such as the calcified microbes, algae, and metazoans, do not fit this model, as they are favorably developed in meso-eutrophic environments [58]. Organisms that precipitated aragonite and high magnesium calcite skeletons advanced during the Ordovician, while organisms with aragonite skeletons such as stromatoporoids, Calathium, and dasycladalean algae were abundant in the Ordovician calcite seas [15]; showing little effect of the ocean's chemical conditions on reef development. A salinity anomaly under an arid climate persisted from the Early to Middle Ordovician, both in the North China and Tarim blocks. Furthermore, the North China Block had more serious high salinity, resulting in large quantities of evaporites and dolostones, and scarce reefs. The Yangtze Platform maintained non-reef carbonate units throughout the Middle-Late Ordovician sequences with limited reef distribution. This was probably caused by the lower oxygen content of the marine water during transgression tracts. Katian reefs flourishing in the local regions of the Yangtze Platform, Tarim, and Ordos were possibly related to the greenhouse Boda Event [59]. Algal reefs may be triggered by climatic changes, and tended to become more abundant globally during icehouse intervals linked to the eutrophication of marine water [60]. The algal reefs at the beginning of the icehouse, from the Daduhe Formation are examples. On the whole, secular climate changes and environmental fluctuations can affect the composition of reef communities. Nevertheless, reefs are ultimately controlled by biotic factors [61]. Based on the evidence from these three blocks in China, Ordovician reefs have occurred over limited time and space. Reef ecosystems are therefore intensely controlled by their environments.

This work was supported by the China Geological Survey Project (1212011120148), the National Natural Science Foundation of China (41072002) and the Knowledge Innovation Program of the Chinese Academy of Sciences (KZCX2-YW-Q05-01). It is a contribution to the IGCP Project 591-The Early to Middle Paleozoic Revolution. We thank the referees for their useful comments on the manuscript.

1 Kiessling W, Simpson C, Foote M. Reefs as cradles of evolution and sources of biodiversity in the Phanerozoic. Science, 2010, 327: 196-198

2 Grotzinger J P, Watters W A, Knoll A H. Calcified metazoans in thrombolite-stromatolite reefs of the terminal Proterozoic Nama Group, Namibia. Paleobiology, 2000, 26: 334-359

3 Riding R. Calcified algae and bacteria. In: Zhuravlev A Y, Riding R, eds. The Ecology of the Cambrian Radiation. New York: Columbia University Press, 2001. 445-473

4 Wood R. The ecological evolution of reefs. Annu Rev Ecol Evol Syst, 1998, 29: 179-206

5 Riding R. Microbial carbonate abundance compared with fluctuations in metazoan diversity over geological time. Sediment Geol, 2006, 185: $229-238$

6 Jaanusson V. Introduction: What is so special about the Ordovician? In: Bruton D L, ed. Aspects of the Ordovician System. Oslo: Palaeont Contri Univ Oslo, 1984. 295: 1-4

7 Sepkoski J J Jr. A compendium of fossil marine families. Milwaukee Publ Mus Contrib Biol Geol, 1982, 51: 1-125

8 Droser M L, Bottjer D J, Sheehan P M. Evaluting the ecological architecture of major events in the Phanerozoic history of marine invertebrate life. Geology, 1997, 25: 167-170

9 Zhan R B, Rong J R. Early to Mid Ordovician brachiopod radiation of South China. In: Rong J Y, ed. Originations, Radiations and Biodiversity Changes-Evidence From the Chinese Fossil Record (in Chinese). Beijing: Science Press, 2006. 259-283, 865-866

10 Zhang Y D, Chen X, Goldman D. Diversification patterns of Early and Mid Ordovician graptolites in South China. Geol J, 2007, 42: 315-337

11 Chen X, Zhang Y D, Fan J X. Ordovician graptolite evolution radiation: A review. Geol J, 2006, 41: 312-326

12 Rong J Y, Fan J X, Li G X. Patterns of latest Proterozoic to Early Mesozoic marine biodiversity changes in South China. In: Rong J Y, ed. Originations, Radiations and Biodiversity Changes-Evidence from the Chinese Fossil Record (in Chinese). Beijing: Science Press, 2006. 785-816

13 Flügel E, Flügel-Kahler E. Phanerozoic reef evolution: Basic questions and database. Facies, 1992, 26: 167-278

14 Kiessling W, Flügel E, Golonka J. Paleoreef maps: Evaluation of a comprehensive database on Phanerozoic reefs. Amer Assoc Petrol Geol Bull, 1999, 83: 1552-1587

15 Webby B D. Patterns of Ordovician reef development. In: Kiessling W, Flügel E, Golonka J, eds. Phanerozoic Reef Patterns. Tulsa: SEPM Spec Publ 72, 2002. 129-179

16 Li Y, Kershaw S, Mu X N. Ordovician reef systems and settings in South China before the Late Ordovician mass extinction. Paleogeogr Paleoclimatol Paleoecol, 2004, 205: 235-254

17 Zhu Z D, Hu M Y, Liu B L, et al. The Study of Early-Middle Ordovician Organic Reefs in China (in Chinese). Beijing: Geological Publishing House, 2006. 1-178

18 Zhu Z D, Liu B L, Meng X F, et al. Early Ordovician organic reefs in Songzi, Hubei (in Chinese). Oil Gas Geol, 1990, 11: 418-426

19 Li G, Wu Q B. The Early Ordovician (Nangjinguan Period) bioherms of northwestern Hunan and its forming environment (in Chinese). J Strat, 2001, 25: 48-50

20 Zhang S G, Tang L. The earliest tabulate coral (early Early Ordovician) in China (in Chinese). Joint Meeting on the 10th National Congress of the Paleontological Society of China (PSC), The 25th Annual Conference of PSC, the Commemoration of the 80th Anniversary of PSC, Abstract Volume. Paleontological Society of China, 2009. 53-54

21 Adachi N, Ezaki Y, Liu J B. Early Ordovician shift in reef construction from microbial to metazoan reefs. Palaios, 2011, 26: 106-114

22 Li Y, Zhang Y Y, Ma J Y, et al. An elementary introduction to reef (in Chinese). In: Sha J G, ed. Proud Paleontology in China across One Century. Beijing: Science Press, 2009. 115-119

23 Mei M X, Lu L C. The baffling buildup reef of Honghuayuanian age, Ordovician in Zhangzhai of Yuping County, Guizhou (in Chinese). Acta Sediment Sin, 1991, 9: 80-89

24 Xiao C T, Cui J L, Zhu Z D, et al. A study on palaeoecology of the Lower Ordovician reefs in the Yichang area, Hubei (in Chinese). Geol Rev, 2004, 50: 520-529

25 Cao J, Liu J B, Yoichi E, et al. Lower Ordovician reefs in the 
Honghuayuan Formation at Dongzi, Anhui: Microbial reefs just prior to the Ordovician Biodiversification (in Chinese). Acta Sci Nat Univ Peking, 2009, 45: 279-288

26 Li Q J, Li Y, Kershaw S, et al. "Middle Member limestone" of the Ordovician Meitan Formation in Dongkala, Fenggang, Northern Guizhou, S W China: Typical warm marine facies. Acta Micropal Sin, 2010, 27: $150-158$

27 Li Y. Late Ordovician to Early Silurian reef evolution in South China (in Chinese). In: Rong J Y, Fang Z J, eds. Mass Extinction and Recovery-Evidences from the Palaeozoic and Triassic of South China. Hefei: University of Science and Technology of China Press, 2004. 207-242

28 Chen X S. Patch reef of Late Ordovician stromatoporoids and corals in Yushan, Jiangxi (in Chinese). Oil Gas Geol, 1996, 17: 326-333

29 Bian L Z, Fang Y T, Huang Z C. Late Ordovician reef types and characters in the border areas of Zhejiang and Jiangxi (in Chinese). In: Fan J S, ed. The Ancient Organic Reefs of China and Their Relations to Oil and Gas. Beijing: Ocean Press, 1996. 54-75

30 Fang Y T, Bian L Z, Shi G J, et al. Patch reefs and their communities of Late Ordovician Sangqushan Formation at Wangjiaba, Yushan County, Jiangxi Province (in Chinese). J Nanjing Univ (Nat Sci), 1993, 29: 670-679

31 Fan D L, James R H, Ye J. Ordovician reef-hosted Jiaodingshan Mn-Co deposit and Dawashan Mn deposit, Sichuan Province, China. Ore Geol Rev, 1999, 15: 135-151

$32 \mathrm{Li} \mathrm{Y,} \mathrm{Feng} \mathrm{H} \mathrm{Z,} \mathrm{Li} \mathrm{J.} \mathrm{Benthic} \mathrm{algae} \mathrm{in} \mathrm{improvement} \mathrm{of} \mathrm{ecologic} \mathrm{crisis}$ of the Late Ordovician in the west margin of the Yangtze Platform (in Chinese). Acta Palaeont Sin, 2002, 41: 211-218

33 Zhou Z Y, Chen X, Wang Z H, et al. Ordovician (in Chinese). In: Zhou Z Y, Chen P J, eds. Biostratigraphy and Geology Evolution of Tarim (4). Beijing: Science Press, 1990. 56-130

34 Ni Y N, Geng L Y, Wang Z H, et al. Ordovician (in Chinese). In: Zhou Z Y, ed. Stratigraphy of the Tarim Basin. Beijing: Science Press, 2001. 39-80

35 Xiao C T, Liu L S, Luo C R, et al. Paleoecology characters of the Ordovician reefs at Lunnan, Tarim Basin (in Chinese). Xinjiang Petro Geol, 1995, 16: 38-42

36 Gu J Y, Zhang X Y, Luo P, et al. Development characteristics of organic reef-bank complex on Ordovician carbonate platform margin in Tarim Basin (in Chinese). Oil Gas Geol, 2005, 26: 277-283

$37 \mathrm{Li} \mathrm{Y}$, Wang $\mathrm{J}$ P, Shen A J, et al. Evolutionary significance of the Calathium reef mound from the Yijianfang Formation, Bachu, Xinjiang (in Chinese). Acta Palaeont Sin, 2007, 46: 347-354

38 Wang G, Yang L M, Zhang Y F, et al. A microbial mound of the Darriwilian (Middle Ordovician) Yijianfang Formation from Well Luoxi 1, eastern Tarim Basin, NW China (in Chinese). Acta Micropalaeont Sin, 2010, 27: 357-365

39 Wang G, Zhang Y F, Yang L M, et al. Transgressive sequences throughout the Yijianfang Formation (Darriwilian, Middle Ordovician) at Well Gucheng 4, Tarim Block, NW China (in Chinese). Acta Micropalaeont Sin, 2011, 28: 137-143

$40 \mathrm{Li} \mathrm{Y}$, Huang Z B, Wang J P, et al. Conodont biostratigraphy and sedimentology of the Middle and Upper Ordovician in Bachu, Xinjiang (in Chinese). J Strat, 2009, 33: 113-122

41 Wang J P, Li Y, Zhang Y Y, et al. Cyanobacterial community from the reef mound of the Lianglitag Formation (Upper Ordovician), Bachu, Xinjiang, NW China (in Chinese). Acta Micropalaeont Sin, 2009, 26: 139-147

42 Yang $\mathrm{H} \mathrm{J}$, Wang J P, Huang Z B, et al. Biota and palaeoecology of the Lianglitag Formation (Katian, Upper Ordovician), Central Tarim, NW China (in Chinese). Acta Palaeont Sin, 2009, 48: 109-122

43 Ye J, Yang Y Y, Xu A D, et al. Ordovician Reefs in South-western Margin of the Ordos Basin (in Chinese). Beijing: Geological Publishing House, 1995. 1-67

44 Ye J, Yang Y Y, Xu A D, et al. Middle Ordovician reefs in the region north of the Weihe River, Shanxi Province, Central China. In: Fan J S, ed. The Ancient Organic Reefs of China and Their Relations to Oil and Gas (in Chinese). Beijing: Ocean Press, 1996. 39-47

45 Zhou Y, Ye J. Late Ordovician reefs in the region north of the Weihe River, Shanxi Province, Central China. In: Fan J S, ed. The Ancient Organic Reefs of China and Their Relations to Oil and Gas (in Chinese). Beijing: Ocean Press, 1996. 47-53

46 Riding R. Microbial carbonates: The geological record of calcified bacterial-algal mats and biofilms. Sedimentology, 2000, 47(Suppl.1): $179-214$

47 Adachi N, Ezaki Y, Liu J B, et al. Early Ordovician reef construction in Anhui Province, South China: A geobiological transition from microbial- to metazoan-dominant reefs. Sediment Geol, 2009, 220: $1-11$

48 Carrera M G, Rigby J K. Section 12. Sponges. In: Webby B D, Paris F, Droser M L, et al., eds. The Great Ordovician Biodiversification Event. New York: Columbia University Press, 2004. 102-111

49 Zhang S G. Exothecal structures of the calathiids and their significance (in Chinese). Acta Palaeont Sin, 1995, 34: 619-635

50 Xia F S, Zhang S G, Wang Z Z. The oldest bryozoans: New evidence from the Late Tremadocian (Early Ordovician) of East Yangtze Gorges in China. J Paleont, 2007, 81: 1308-1326

51 Webby B D, Elias R J, Young G A, et al. Section 15. Corals. In: Webby B D, Paris F, Droser M L, et al., eds. The Great Ordovician Biodiversification Event. New York: Columbia University Press, 2004. 124-146

52 Webby B D. Section 13. Stromatoporoids. In: Webby B D, Paris F, Droser M L, et al., eds. The Great Ordovician Biodiversification Event. New York: Columbia University Press, 2004. 112-118

53 Pratt B R, James N P. Cryptalgal-metazoan bioherms of Early Ordovician age in the St. George Group, western Newfoundland. Sedimentology, 1982, 29: 543-569

54 Pratt B R, James N P. Coral-Renalcis-thrombolite reef complex of Early Ordovician age, St. George Group, western Newfoundland. In: Geldsetzer H H J, James N P, Tebbutt G E, eds. Reefs, Canada and Adjacent Areas. Can Soc Petrol Geol Mem 13, 1989. 224-230

55 Feng H Z, Yu J H, Fang Y T, et al. The palaeosalinity analysis of Upper Yangtze Sea in Wufengian (in Chinese). J Strat, 1993, 17: 179-185

56 Riding R. Temporal variation in calcification in marine cyanobacteria. J Geol Soc, 1992, 149: 979-989

57 Kauffman E G, Fagerstrom J A. The Phanerozoic evolution of reef diversity. In: Ricklefs R E, Schluter D, eds. Species Diversity in Ecological Communities: Historical and Geographical Perspectives. Chicago: University of Chicago Press, 1993. 315-329

58 Wood R. Nutrients, predation and the history of reef-building. Palaios, 1993, 8: 526-543

59 Boucot A J, Rong J Y, Chen X, et al. Pre-Hirnantian Ashgill climatically warm event in the Mediterranean region. Lethaia, 2003, 36: $119-132$

60 Kiessling W. Paleoclimatic significance of Phanerozoic reefs. Geology, 2001, 29: 751-754

61 Kiessling W. Geologic and biologic controls on the evolution of reefs. Annu Rev Ecol Evol Syst, 2009, 40: 173-192

Open Access This article is distributed under the terms of the Creative Commons Attribution License which permits any use, distribution, and reproduction in any medium, provided the original author(s) and source are credited. 